\title{
REPRESENTATION OF THE USA IN THE CONTEXT OF IMPERIALISM IN THE PROPAGANDA POSTERS PUBLISHED IN THE PEOPLE'S REPUBLIC OF CHINA
}

\author{
Caner Çaki ${ }^{1}$, Hakan Aşkan ${ }^{2}$, Mustafa Karaca ${ }^{3}$, Emrah Durmaz $^{4}$
}

\begin{abstract}
A negative process started in Sino-USA relations after establishing the People's Republic of China (PRC), PRC made policies against the USA, which it accused of being imperialist. Tensions between China and the USA led to the presentation of the USA to the masses as an imperialist country and the national enemy of Chinese people in Chinese media. The study tried to reveal how the USA was presented to the masses and through which messages it was built as an enemy country in the context of imperialism in anti-US posters in China. For this purpose, 8 posters determined within the scope of the study were analyzed in the light of the German linguist Karl Bühler's Organon Model, using the semiotic analysis method. As a result of the study, it was claimed in the posters that the USA had imperialist goals and led to war to achieve these goals. For this reason, the message that the imperialist aims of the USA posed a threat to both China and world nations, and world nations must act against the USA in order to end the danger posed by the USA was given. Thus, the Chinese administration tried to legitimize the anti-USA policies implemented during the Cold War.
\end{abstract}

UDC Classification: 327.2, 327.5, 327.8, DOI: https://doi.org/10.12955/pss.v2.204

Keywords: China, media, culture, USA, imperialism, representation.

\section{Introduction}

The foreign legitimation of the PRC opened its door at the start of the 1970s (Cukierman and Tommasi, 1998: 180), and the relations between the US and China went on positively. Until then, the US discourses by the PRC and the notion of imperialism were identified as a threat in Chinese society, while the USA was built as a national enemy.

In recent years, various studies on ideology and propaganda were made by using semiotics method in Turkey (Çakı et al., 2017; Aşkan and Mermer Üzümlü, 2020; Çakı et al., 2020; Gazi et al., 2020; Gazi et al., 2021). The research aims to demonstrate how the PRC media portrays the phenomenon of imperialism and how the USA, by imperialism, is portrayed in the media. The thesis looks at the Chinese media from 1949-1971, when relations between the PRC and the US were more fraught, and the PRC accused the U.S. of seeking imperialist goals. In this report, a total of 19 posters related to the topic will be discussed posters, which stand out as one of the most powerful mass media resources during this time. Since posters are identical in subject matter and material, there are limitations to the study, and eight posters that the study is meant to represent the world better. The German linguistic Karl Bühler's Organon Model analyzes eight posters as samples in the analysis using the semiotic approach. The study is important in terms of reflecting the phenomenon of imperialism and the representation of the USA in the Chinese media, providing information about China-USA relations during the Cold War period, and revealing what messages the Chinese administration gave in the international arena through the imperialism discourse.

\section{The Phenomenon of Imperialism in Chinese Culture}

Imperialism is an ideology that expresses the effort of a country to control and influence the governments of other countries, usually with the military, political or economic power. The concept of imperialism in the 19th and 20th centuries comes to the fore in the discourses about China due to the economic influence Western countries have established on China. There is a perception that the great powers of Europe are trying to achieve their imperialist goals on Chinese territory and that China is under the economic threat of the imperialist powers. With the loss of the First Opium War against England between 1839-1842 (Caquet, 2015: 1009) and the Second Opium War against Britain and France between 1856-1860, China offers economic concessions to England. This process is interpreted as the effect of economic imperialism on China and the first formation of the concept of imperialism in Chinese

\footnotetext{
${ }^{1}$ Inönü University, Faculty of Communication Sciences, Department of Public Relations and Advertising, ORCID: 0000-0002-1523-4649, Web of Science ResearcherID: AAG-7018-2020, caner.caki@inonu.edu.tr ${ }^{2}$ Inönü University, Faculty of Communication Sciences. Department of Radio Television and Cinema. ORCID: 0000-0001-9627-5911, Web of Science Researcher ID: AAE-2373-2021, hakan.askan@inonu.edu.tr ${ }^{3}$ Faculty of Economics and Administrative Sciences, Anadolu University, Eskişehir, Turkey, Orcid ID: 00000002-8204-6154, Web of Science Researcher ID: ABG-4136-2020, mustafa_karaca@anadolu.edu.tr ${ }^{4}$ Graduate School of Social Sciences, Department of Civil Aviation Management, Anadolu University, Eskişehir, Turkey, Orcid ID: 0000-0002-6917-5031, Web of Science Researcher ID: ABI-2406-2020, emrahdurmaz@anadolu.edu.tr
} 
culture in the modern sense emerges with the opium trade. As China entered the 20th century, it managed to maintain its independence under the rule of the Qing Dynasty (1644-1911) without being under the sovereignty of any country. On the other hand, Western states obtain important economic privileges from China, and the concept of imperialism in Chinese culture is identified with Western states due to the economic privileges obtained. At the end of the 19th century, discontent increased within the country against the economic existence of foreign countries over China, nationalist feelings became stronger, and eventually, the anti-imperialist Boxer Uprising took place on November 2 1899. The basis of the revolt is the removal of the Western powers from China and the independent economic actions of China. The organizers of the uprising were targeting Western states by using anti-imperialist rhetoric. After the rise of the rebellion, The Alliance of Eight Nations was formed by the Western States, and the revolt was crushed strongly. The Boxer Protocol was signed on September 7, 1901 (Van de Ven, 2006: 631), and the uprising came to an end. The suppression of the Boxer Uprising put China under full control of the Western states.

In 1911, the Chinese Dynasty collapsed, and the Republic of China was established on January 1, 1912. After the establishment of the Republic of China, the Kuomintang (Chinese Nationalist Party) and the Chinese Communist Party (CCP) engaged in struggle, and the struggle between the two groups led to the Chinese Civil War on August 1, 1927. While the Chinese Civil War was continuing, Japan began to occupy China on July 7, 1937, and the civil war ended temporarily. The Japanese occupation continued in China between 1937-1945 (Che et al., 2015: 182), and Japan became the target of anti-imperialist discourses in the Chinese media. The Kuomintang and CCP were trying to act together against Japan, which has become the national enemy in Chinese culture. In the Chinese media, the Chinese soldiers fighting against Japan were presented as national heroes and the perception created was that they defeated the Japanese soldiers. With the defeat of Japan in World War II and its withdrawal from China in 1945, the civil war between the Kuomintang and the CCP continued. The leader of the CCP, Mao Zendong, declared that he founded the People's Republic of China (PRC) on October 1, 1949, and ended the civil war by defeating the Kuomintang forces in 1950 (Liu, 2006: 483). The leader of the Kuomintang, Chiang Kai-shek moved to Taiwan and continued to rule there. During this period, the US turned to policy against PRC and decided to recognize Chiang Kai-shek's Taiwan administration. With the hostile attitude of the USA towards the PRC and its support to the Kuomintang, the Chinese administration engaged in anti-US policies, and the USA became the country where imperialism is identified after Japan in Chinese culture. At this stage, the Taiwan administration is declared a national enemy in social and cultural life in China, while the USA is being presented as an imperialist country that supports China's national enemy.

\section{Representation of the USA in the Chinese Media in the Context of Imperialism}

After the Chinese Revolution in 1911, the USA accepted the Republic of China as the sole and legitimate administration of the country. After Japan invaded the Republic of China in 1937, the United States sided with the Republic of China and helped the Republic of China. During the Japanese invasion of China, the US was brought to the fore as a friendly and allied country in the Chinese media. The US media had a pro-Chinese stance, The Nanking Incident was announced to the US public, and the US public condemned what was happening in China. After Japan's attack on Pearl Harbor on December 7, 1941 (Hone, 2017: 71), the USA declared war on Japan and became a direct ally with China, which is fighting against Japan. During the Chinese Civil War that started after the Second World War, the US decided to support the Kuomintang against the CCP. The US administration feared that if the CCP was victorious in the civil war, the Soviet Union would use its ideological affinity to gain influence over China. At this stage, US hostility to the Chinese Communist Revolution also disturbed Mao and other CCP leaders (Jian, 1995: 23). The establishment of the PRC and the conclusion of the Chinese Civil War in favor of the CCP lead to the negative development of China-US relations. The US did not recognize the PRC, which dominates the mainland of China, and instead maintained the diplomatic relations of Chiang Kai-shek with the Taiwan administration as the only legitimate government related to China. The United States (Baijia, 2001: 47), which openly supports the Taiwan administration, also gave the message that if the PRC invades Taiwan, the US will directly intervene against the PRC. The US siding with the Taiwan administration caused China's hostility towards Taiwan. In addition, this has 
also the US to be presented as an imperialist country in the Chinese media that supports the enemies of the PRC.

In the Korean War, which started right after the end of the Chinese Civil War, the USA attacked North Korea, supported by the PRC, and threatened the Chinese border. The US-led international coalition forces forced North Korean forces to withdraw from South Korea in the war and were also approaching the Chinese border. Thereupon, the CCP (Won, 2014: 91), which entered into cooperation with North Korea during the Chinese Civil War, started a general attack targeting the USA and its allies towards the end of 1950, causing heavy losses and forcing the USA and its allies to withdraw from North Korea. The Korean War caused both China and the USA to suffer heavy losses; at the same time, it negatively affected the relations between China and the USA, and it was only after twenty years the relations of both countries have recovered (Yufan and Zhihai, 1990: 94). Regarding the war, the Chinese media continues to identify the US with the phenomenon of imperialism, thereby trying to create a strong antiUS public opinion. The USA, which intervened in foreign countries (Hunter, 2018: 88), is presented as a country that invaded North Korea in order to realize its so-called imperialist goals, on the other hand, there are reports that the Chinese and North Korean forces have severely defeated the US troops. At this stage, while the Chinese army is represented as a strong army in the Chinese media, the USA was transferred to the masses as a weak and easily defeated army. After the ceasefire agreement was signed between the parties in the Korean War in 1953, the relations between China and the USA continued to run negatively. In the US media, some statements directly target the ideology of Communism and present Communism as an enemy. The hostile rhetoric of the US media negatively affected the Soviet Union as well as the PRC, which is governed under the ideology of Communism. In the course of the Vietnam War that started in 1955, the USA's direct intervention in the war caused the tension in ChinaUSA relations to escalate again. By supporting the North Vietnamese forces rather than directly intervening in the Vietnam War, China negatively affected the US presence in the region. During the Vietnam War, the Chinese media continued to accuse the US as an imperialist country, and it was alleged that the US participated in both the Korean War and the Vietnam War to realize its own interests. On the other hand, despite the US positioning China as a weak country (Jian, 1995: 23), the perception in the Chinese media was that the USA is a power that can be easily defeated. After Richard Nixon took office as president of the USA in 1969, radical changes began to occur in China-US relations. After the China-Soviet border conflict in 1969, the PRC chose to develop its relations with the USA in a positive way while pursuing a policy against the Soviet Union. With the new administration, the USA believed that China would be an effective balance against the Soviet threat (Wang and Lin, 1992: 902). The effect of Nixon's surprising visit to the PRC in 1972 enabled other countries to develop their relations with China positively (Briscoe and Safford, 2008: 460). The rapprochement between the USA and China, which started in the early 1970s, caused both countries to abandon their mutually hostile policies, and in this process, the target of the Chinese media began to be the Soviet Union, not the USA. Especially during the Cultural Revolution, the new enemy in the Chinese media was Soviet revisionism rather than American imperialism, and the post-Stalin discourses of the Soviet Union were harshly criticized in the Chinese media. At this stage, contacts between the USA and China developed in the 1970s, diplomatic relations were established, and this process expanded after China's economic reforms were initiated in the late 1970s (Wang, 1999: 249).

\section{A Semiotic Analysis of US Representation in Chinese Posters on Imperialism}

Eight posters titled Aggressors, Peace, Revolt, Politics, Attack, Siege, Exclusion, and Reaction, determined as a sample in the study and are examined using the semiotics method specific to the Organon Model.The Organon Model (Organon-Modell) is a communication model introduced by the German linguist Karl Bühler (1879-1963) in 1934 (Eschbach, 1989: 119). In the model, it is argued that the communication process takes place in three basic dimensions, which are Expressive function (Ausdrucksfunktion), representation function (Darstellungsfunktion), and Volition function (Appellfunktion). The expressiveness function focuses on how the source uses the indicators to create a message in the communication process. The representation function focuses on how the objects and concepts used in the communication process are interpreted in the indicator dimension. Finally, the volition function emphasizes what the recipient should do, what attitude, and how he/she should act on the indicators used in the communication process (Scherer, 1992: 44). In the posters of the study, firstly, it is tried to be explained how the indicators are used in the dimension of expressiveness function, then 
which meanings are put through the indicators in the representation function, and finally which messages are given to the masses in the function of request.

The study's main hypothesis is the inference that the US administration is tried to be identified with the concept of imperialism through the propaganda posters prepared in the PRC. At this stage, the following questions were tried to be answered;

1. How is the USA represented in the Chinese media through the imperialism discourse?

2. In the hate speech made in Chinese media against the United States, what problems are highlighted?

3. What are the messages on globalization in the Chinese media in the world arena? There is an attempt to address questions such as these.

\section{Aggressors Poster}

The aggressor's poster was made in 1952, and there is no information about the people who prepared the poster. When examined through the expressive function, it is seen that the poster depicts a group of soldiers with a gun and another group of soldiers surrendering by raising their hands up. The poster reflects that the soldiers who surrender are tired and exhausted, and in the background of the poster, a mountainous area and different soldier images are displayed. At the bottom right of the poster, dead soldiers, a shattered tank, and a shattered US flag are depicted, and the poster features the fate of the aggressors. After the defeat of the North Korean troops by the United Nations (UN) forces in the Korean War (1950-1953), the first major hot war of the Cold War, China joined the war in favor of North Korea. With the help of the Soviet Union, a triangle alliance of China-Soviet-North Korea was formed (Shen, 2010: 211). Considering the representation function, the poster prepared in the second year of the Korean War reveals that the defeat of the UN forces by the Chinese and North Korean troops in North Korea was the event that was pictured in the poster. When examined through the volition function, the message is given through the text on the poster that the US soldiers attack North Korea, and through the images, China and North Korea are the parties that defend their lands.

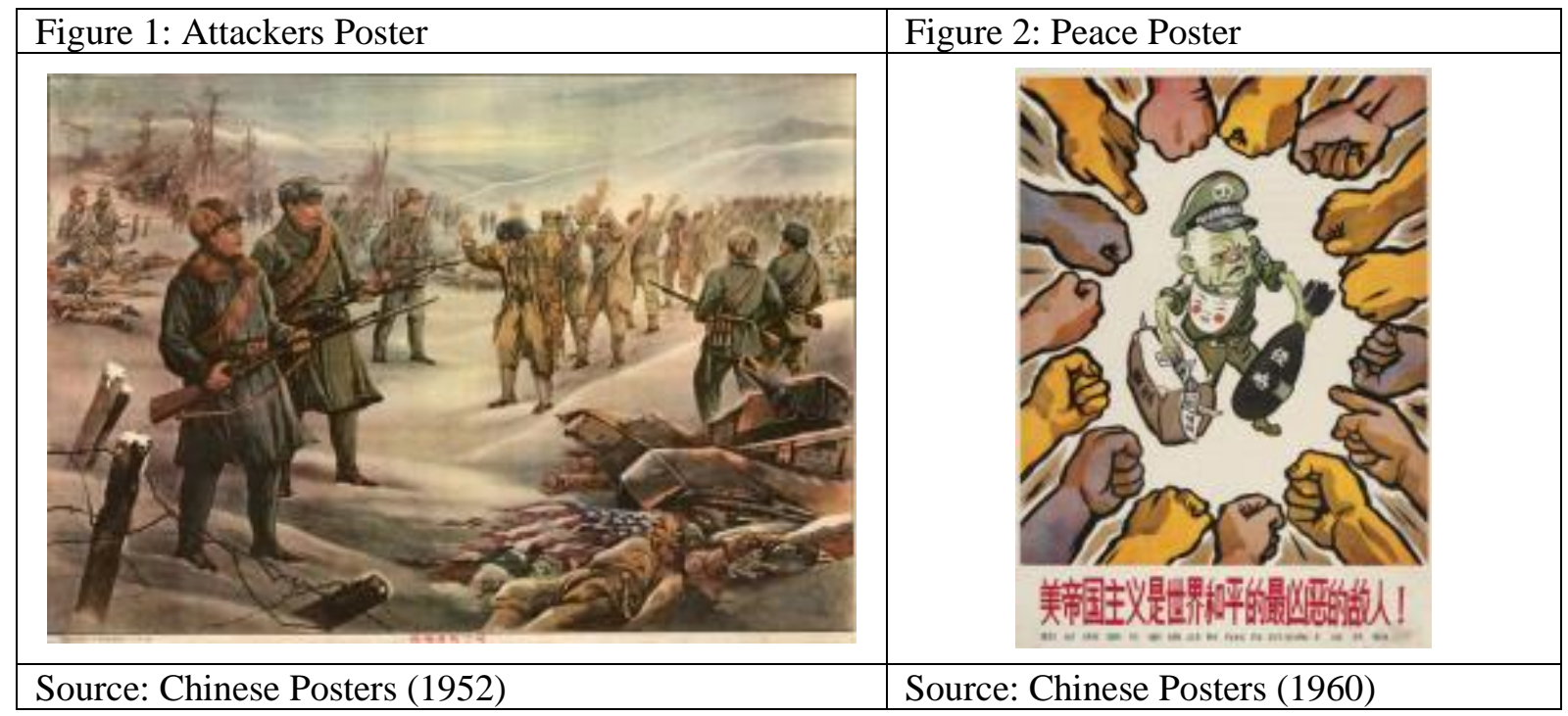

\section{Peace Poster}

The peace poster was made in 1960 by Zhou Anqi and Yuan Jiqing. Considering the expressiveness function, it is seen that the poster depicts a soldier with a knife and papers in one hand and a bomb in the other hand. In the image, the soldier has the letters the US on his hat, the US dollar sign on his left arm, and a laughing mask around his neck. The soldier is depicted surrounded by hands of different colors, punching and pointing his index finger. On the poster, it is written, 'American imperialism is the most deceiving enemy of world peace!'. Until the early 1970s, China regarded the USA as a capitalist country that threatened the existence of China (Wang and Lin, 1992: 902). Similarly, the US is presented in the poster as an imperialist state that threatens world peace. When examined through the representation function, the message that it gives is that the soldier is a US soldier. Considering the function of demand, it is claimed that the statements on the poster and the statements of the USA to achieve world peace are not true and that the imperialist goals of the USA threaten world peace. 


\section{Revolt Poster}

Zhao Yannian made the revolt poster in 1964. When examined through the expressive function, the poster depicts a person of color with a gun calling people behind him in one direction. It is reported that the person in color wears one of the African indigenous clothes, and the people who wear the local clothes of different nations follow him. In the poster, there is a visual of a black person fighting with a soldier with US on his hat and a gun in his hand. The poster reads that the oppressed peoples of the world are uniting and resolutely opposing American imperialism. In 1964, when the poster was published, many countries around the world, especially the African continent, were governed by Western countries. On the other hand, on this date, some countries allowed Western countries to establish military bases in their territories in line with the agreements they made with the Western Bloc countries. China considers American imperialism as its primary external enemy (Baijia, 2001: 47), at this stage turning towards harsh rhetoric against the USA. When considered in terms of the representation function, the message is given that the peoples of the states under the sovereignty of Western powers or cooperating with Western powers are in struggle. When examined through the function of demand, a perception is created in the poster that imperialism affects the nations of the world negatively, and the USA is targeted as the source of imperialism in this process.

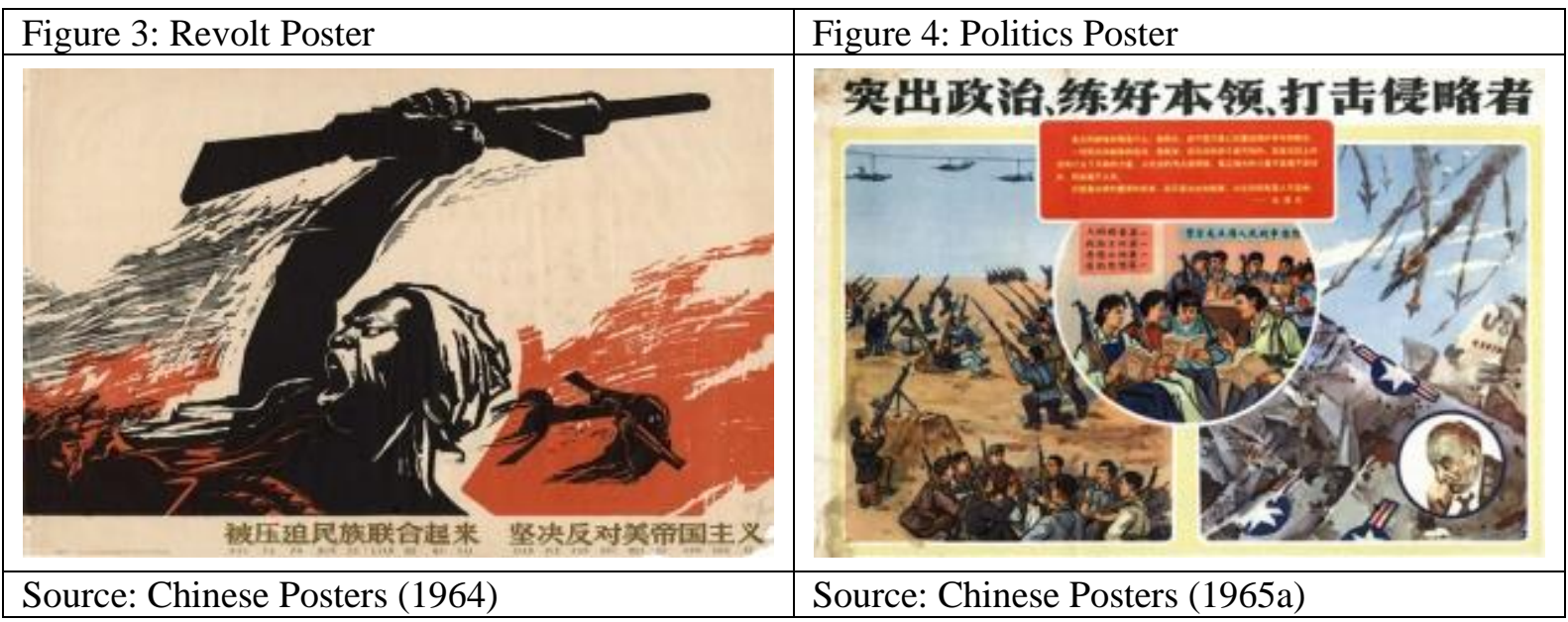

\section{Politics Poster}

The policy poster was made in 1965 and there is no information about the people who prepared the poster. Considering the expressiveness dimension,it is seen that the poster consists of three different parts. In the first part, civilians turn their weapons into model planes. In the second part, civilians carry weapons and read books, in the third part, the images of falling aircraft and parachutes and plane wrecks on the ground are depicted. In the third part, there is a symbol of the US Air Force on the plane wrecks and a thoughtful picture of the US President Lyndon Baines Johnson. There is an laconism on the poster about paying attention to politics, developing your skills, and attacking the aggressors. In the period when the poster was published, the Vietnam War continued, and the US President Johnson escalated the war in Vietnam in order to preserve the global credibility of America as the leader and defender of the non-Communist world in the face of the threat posed by China in Vietnam (Lin, 2009: 35). When examined through the function of representation, it is stated in the poster that the Johnson administration was targeted, the Chinese people were prepared for the struggle against the USA, and that this struggle was tried to be encouraged. When considered in the aspect of the request function, it is claimed from the writings on the poster that the USA follows an aggressive policy and is a potential enemy for the Chinese people.

\section{Attack Poster}

The attack poster was made by Ha Qiongwen in 1965. When examined through the expressive function, the poster depicts a man trying to get through the barbed wire with the people behind him. It is seen that the male in the foreground in the poster squeezes the barbed wire with one hand and directs the people behind him forward with the other hand. On the right side of the poster, it is reported that an Uncle Sam puppet was hung and burned. 'American imperialists get out of South Korea!' was also written on the poster. The Korean War ended in 1953 (Yufan and Zhihai, 1990: 94), while the US military forces continued to exist in South Korea. Considering the representation function dimension, it is revealed that 
the US military power in South Korea is the subject of the poster. When examined through the function of demand, it is claimed that the imperialist aims of the USA are at the basis of the USA's presence in South Korea.

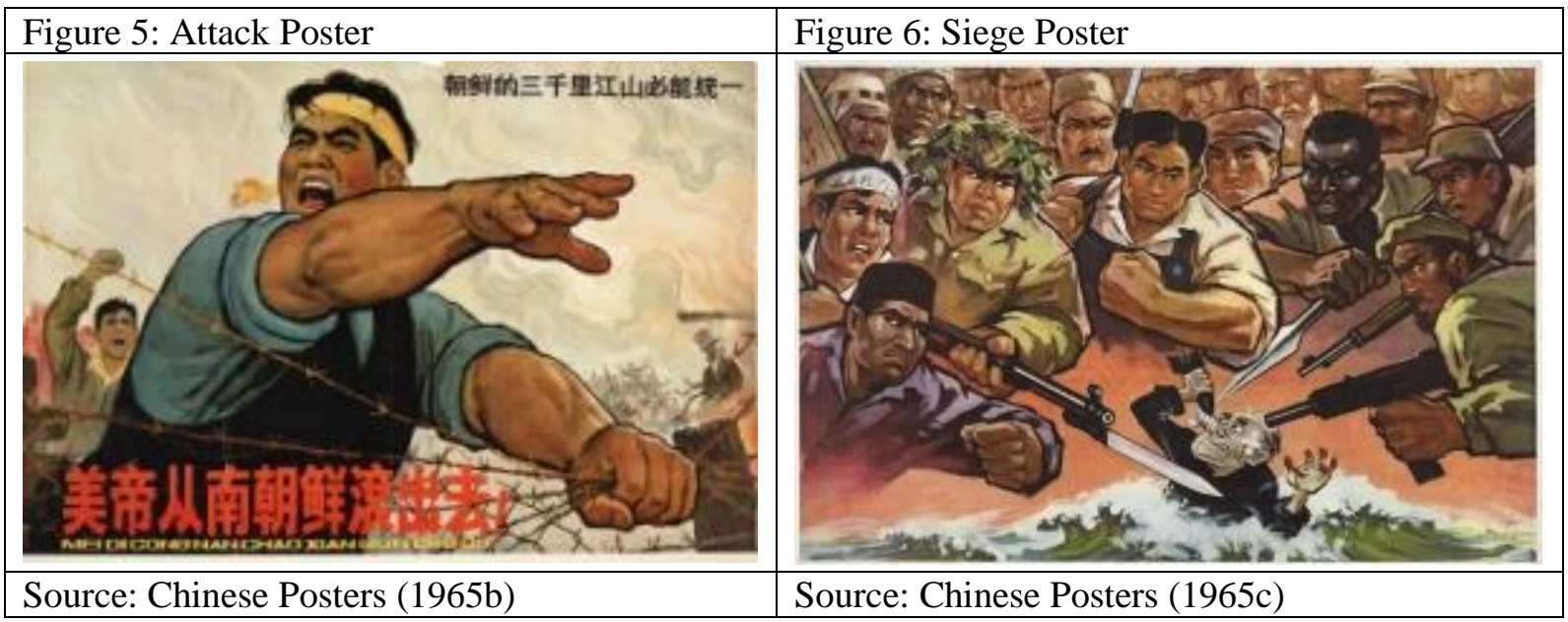

Source: Chinese Posters (1965b)

Source: Chinese Posters (1965c)

\section{Siege Poster}

The siege poster was made by Lu Shaoquan in 1965. Considering the expressiveness function in terms of its function, it is seen that gunmen surround the US President Johnson in waves, portrayed in a larger way than himself in the poster. The poster depicts Johnson with bandages on his nose, a band-aid on his face, a bomb in one hand, and blood on the other hand's fingers. The people surrounding Johnson are depicted of different races and wearing different local outfits. The poster expresses that American imperialism is surrounded by the people of the world.

During the Vietnam War, US President Johnson resisted proposals to adopt a flexible stance against China in the first two years of his presidency, suspected of supporting and encouraging Communist expansion in South Vietnam (Lumbers, 2004: 68). At this stage, the strict policy of the USA towards China led to the targeting of the USA in the Chinese media, particularly Johnson. When examined through the function of representation, the poster tries to create a perception that the nations of the world are fighting against the USA. Considering the function of demand, it is claimed in the poster that the USA can be built as an imperialist country before the masses and that the USA can kill people for its imperialist purposes.

\section{Exclusion Poster}

The exclusion poster was made by Chen Yongzhi in 1965. When examined through the expressiveness function, it is seen that there are children of different races and in different local clothes in the poster. One of the children is reported to be carrying crutches wrapped around his feet, a pointed cone on his nose, wearing a top hat in the shape of a USA flag, and lying on the ground. Except for the child lying on the floor, everyone has toy guns, two of the children point a gun at the child lying on the ground, and two of them show the child lying on the ground with their index finger. There is the word "Down With Yanki" on the poster. The tension between China and the USA continued at the time the poster was published, and the Chinese administration continued its harsh anti-US rhetoric. On the other hand, the USA also tries to isolate China (Cohen, 2007: 148) and tries to persuade its allies to impose an embargo on China (Cain, 2005: 131). Considering the representation function, the poster reveals that China is trying to create an anti-US public opinion. When examined through the volition function, the nations of the world are called to fight against the USA through the images of children in the poster, and the message is given is that the US forces can be defeated if they act together.

\section{Obscurantism Poster}

The obscurantism poster was made in 1965 by Chen Xiaoxi and Guo Kekuan. Considering the expressiveness function, it can be seen that the poster depicts a man with a gun in one hand and the other on his waist, in a Chinese soldier uniform, with three medals on his chest. There is an image of the sun with soldiers and civilians carrying guns, looking in a certain direction behind the man. At the bottom of the gun's bayonet held by the man in the foreground in the poster, there is a torn Japan Flag, a fragmented Kuomintag logo on one top, and a pierced soldier helmet with the US on it at the top. The 
poster reflects Imperialism and all obscurantism as completely empty enemies. In the first half of the 20th century, Japan and the Kuomintang forces were the two great powers that China struggled with. China suffered heavy losses in its struggle against both powers, and both powers are presented as two dangerous enemies in Chinese culture. China promotes US imperialism as an obscurant and vulnerable and tries to promote the national self-esteem of the Chinese people (Jian, 1995: 23). When examined through the function of representation, it is revealed that the forces that China struggled within the 20th century are reflected in the poster. When considered in the aspect of the demand function, it is revealed that the Chinese administration reflects the USA as a dangerous enemy to the masses as much as Japan occupying China and the Kuomintang, which is the opposite front of the civil war.

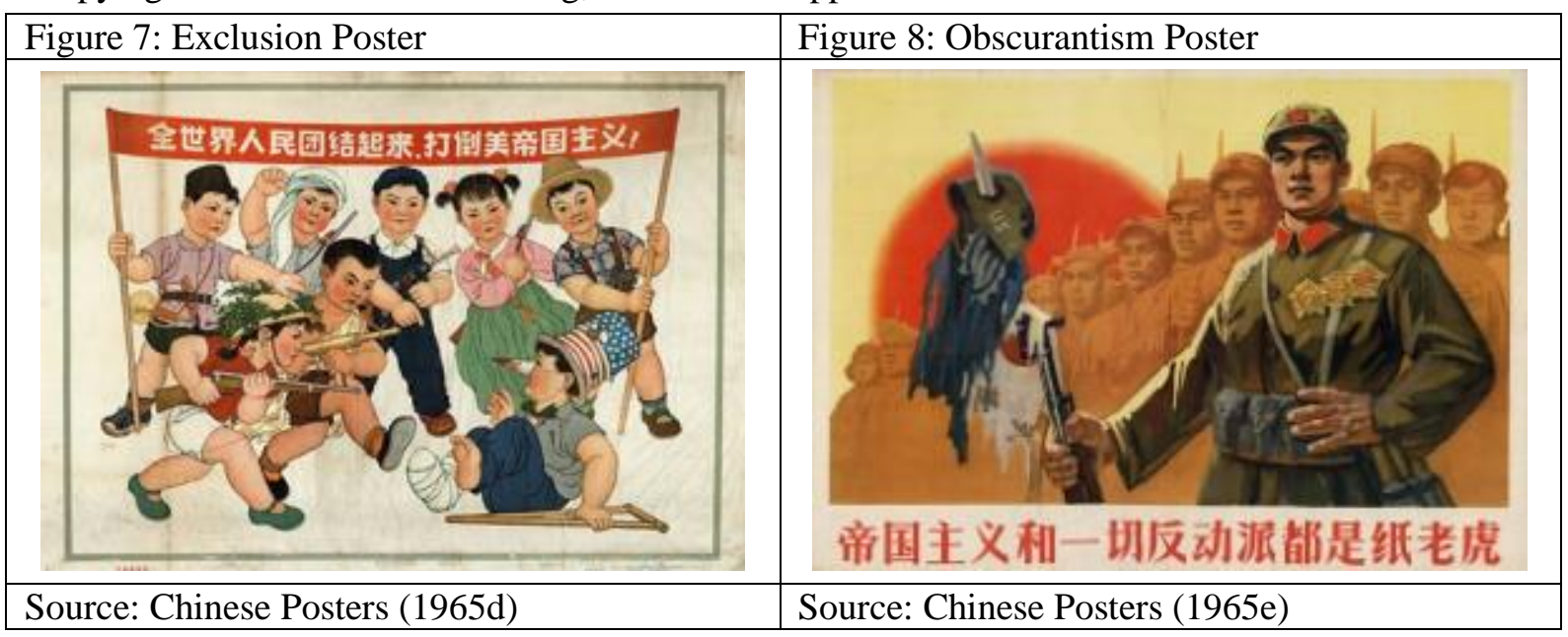

\section{Conclusion}

Based on the posters examined in the study, it is claimed that the USA is an imperialist country. It is claimed that the USA made military interventions in other countries to realize the USA's so-called imperialist aims. In this way, the perception is created that the USA is following an invasive and expansionist policy through posters, and it is claimed that the US administration poses a threat to China, like other countries. The Chinese media gives the message that China should defend itself and take precautions against the so-called aggressive policies of the USA. In this way, the Chinese administration aims to mobilize the masses in anti-US defense activities and legitimize its anti-US policies. When evaluated in general, it is revealed that the Chinese administration has benefited from the imperialism fact that it has brought to the forefront as a threat factor in this process when it tries to build the USA as an enemy country for both China and humanity. The posters attempt to create hate speech against the United States only with claims that the USA is an aggressive, invading, and peace-threatening imperialist country, whereas there is no content or specific situation that proves the claims in the posters. A striking issue in the posters examined is that there are no statements expressing the ideology of Communism in the posters. Any Marxist-Leninist sign that was glorified in the Chinese media after the establishment of the PRC is not used in the posters. Another remarkable detail is that Mao's image or name is not included in the posters examined. Mao, who was the leader of the PRC at the time the posters were published, has a strong personality cult in his country as it is today and is presented to the masses through the media as the savior of the Chinese people. In this respect, it can be mentioned that the posters do not include the ideology of Communism and Mao, and the posters aim to focus the masses on the hate speech used against imperialism and the USA.

\section{References}

Aşkan, H., \& Üzümlü, A. M. (2020). "Soğuk Savaş Dönemi'nde Özgür Avrupa Radyosu'nu Konu Alan 'Gerçekliğin Kuleleri' Adlı Kısa Film Üzerine İnceleme". Anadolu Akademi Sosyal Bilimler Dergisi, 2(1), 71-92.

Cain, F. (2005). "Computers and the Cold War: United States Restrictions on the Export of Computers to the Soviet Union and Communist China". Journal of Contemporary History, 40(1), 131-147. DOI: 10.1177/0022009405049270.

Caquet, P. E. (2015). "Notions of Addiction in the Time of the First Opium War". The Historical Journal, 58(4), 1009-1029. DOI: $10.1017 / \mathrm{S} 0018246 \mathrm{X} 14000739$.

Che, Y., Du, J., Lu, Y., \& Tao, Z. (2015). “Once An Enemy, Forever An Enemy? the Long-Run Impact of the Japanese Invasion of China from 1937 to 1945 on Trade and Investment". Journal of International Economics, 96(1), 182-198. DOI: 10.1016/j.jinteco.2015.01.001. 
Chinese Posters (1952). Qinlüezhede xiachang. Retrieved November 5, 2021 from https://chineseposters.net/posters/pc-1952001

Chinese Posters (1960). Mei diguo zhuyi shi shijie hepingde zui xiong'ede diren! Retrieved November 5, 2021 from https://chineseposters.net/posters/pc-1960-001

Chinese Posters (1964). Bei yapo minzu lianhe qilai jianjue fandui Mei diguo zhuyi. Retrieved November 5, 2021 from https://chineseposters.net/posters/e37-508

Chinese Posters (1965a). Tuchu zhengzhi, lianhao benling, daji qinlüezhe. Retrieved November 5, 2021 from https://chineseposters.net/posters/e15-198

Chinese Posters (1965b). Meidi cong Nanchaoxian gunchuqu!. Retrieved November 5, 2021 from https://chineseposters.net/posters/g2-684

Chinese Posters (1965c). Mei diguo zhuyi zai quan shijie renminde chongchong baowei zhi zhong. Retrieved November 5 , 2021 from https://chineseposters.net/posters/pc-1965-001

Chinese Posters (1965d). Dadao Meiguolao. Retrieved November 5, 2021 from https://chineseposters.net/posters/pc-1965011

Chinese Posters (1965e). Diguo zhuyi he yiqie fandongpai dou shi zhilaohu. Retrieved November 5, 2021 from https://chineseposters.net/posters/e15-615

Cohen, W. I. (2007). "Chinese Lessons Nixon, Mao, and the Course of U.S.-Chinese Relations". Foreign Affairs, 86(Number 2), 148-154.

Cukierman, A. ve M. Tommasi (1998). “When Does It Take a Nixon to Go to China?”. American Economic Review, 88(1), 180-197.

Çakı, C., Zorlu, Y. \& Karaca, M . (2017). "Nazism Ideology in Turkish Cinema: 'Kirimli' Film and Semiotics Analysis". Sosyoloji Konferanslarl, (56), 67-95. DOI: 10.18368/iusoskon.328523

Çakı, C., Gazi, M. A., Çakı, G. \& Gülada, M. O. (2020). "Likbez Kampanyası Dönemindeki Propaganda Posterleri Üzerine Göstergebilimsel Bir İnceleme". Türk Kütüphaneciliği, 34(4), 663-692. DOI: 10.24146/tk.806892

Eschbach, A. (1989). The Characteristics of Karl Buhler's Pragmatically Integrated Theory of Signs. Semiotics and Pragmatics: Proceedings of the Perpignan Symposium. (Ed. G. Deledalle). Holland: John Benjamins Publishing Company.

Gazi, M. A., Çakı, C., Gülada, M. O. \& Çakı, G. (2020). "Çin Halk Cumhuriyeti Kültür Devrimi Sürecinde Okuma Alışkanlığının Propaganda Posterlerinde Sunumu". Türk Kütüphaneciliği, 34(3), 406-431. DOI: 10.24146/tk.778685

Gazi, M. A., Çakı, C., Karaca, M., Çakı, G. (2021). "An Examination of the Propaganda Posters in the 1980 Nicaragua Literacy Campaign in the Context of Reading Books". Türk Kütüphaneciliği, 35(1), 64-88. DOI: 10.24146/tk.873618

Hone, T. (2017). The Evolution of Fleet Tactical Doctrine in the US Navy, 1922-1941. The Second World War. (Ed. J. Black). The United Kingdom: Routledge. DOI: 10.1353/jmh.2003.0300.

International Institute of Social History (n.d.) Fulltext search for "China poster Mao Tse-Tung“. Retrieved September 16, 2020 from https://search.socialhistory.org/Search/Results?\&format\%3A\%22Visual+documents\%22\&lookfor= China+poster+Mao+Tse-Tung

Jian, C. (1995). China's Road to the Korean War: The Making of the Sino-American Confrontation. The United States: Columbia University Press.

Lin, M. (2009). "China and the Escalation of the Vietnam War: the First Years of the Johnson Administration". Journal of Cold War Studies, 11(2), 35-69. DOI: 10.1162/jcws.2009.11.2.35.

Liu, L. (2006). "The Man who Molded Mao: Yang Changji and the First Generation of Chinese Communists". Modern China, 32(4), 483-512. DOI: 10.1177/0097700406290790.

Lumbers, M. (2004). "The Irony of Vietnam: The Johnson Administration's Tentative Bridge Building to China, 19651966”. Journal of Cold War Studies, 6(3), 68-114. DOI: 10.1162/1520397041447373.

Scherer, K. R. (1992). Vocal Affect Expression as Symptom, Symbol, and Appeal. Nonverbal Vocal Communication: Comparative and Developmental Approaches. (Ed. H. Papousek, U. Jürgens ve Mechthild Papoušek). The United Kingdom: Cambridge University Press

Shen, Z. (2010). "China and the Dispatch of the Soviet Air Force: The Formation of the Chinese-Soviet-Korean Alliance in the Early Stage of the Korean War". The Journal of Strategic Studies, 33(2), 211-230. DOI: 10.1080/01402391003590291.

Van de Ven, H. (2006). "Robert Hart and Gustav Detring during the Boxer Rebellion". Modern Asian Studies, 40(3), 631662.

Wang, J. ve Z. Lin (1992). "Chinese Perceptions in the Post-Cold War Era: Three Images of the United States". Asian Survey, 32(10), 902-917. DOI: 10.2307/2645048.

Wang, Z. (1999). "US-China Scientific Exchange: A Case Study of State-Sponsored Scientific Internationalism during the Cold War and Beyond". Historical Studies in the Physical and Biological Sciences, 30(1), 249-277. DOI: 10.2307/27757826.

Won, K. S. (2014). "The Chinese Civil War and Sino-North Korea Relations, 1945-50". Seoul Journal of Korean Studies, 27(1), 91-113. DOI: 10.1353/seo.2014.0001

Yufan, H. ve Z. Zhihai (1990). “China's Decision to Enter the Korean War: History Revisted”. The China Quarterly, 121, 94115. DOI: $10.1017 / \mathrm{S} 0305741000013527$. 